RESEARCH PAPER

\title{
Effect of Home Assignments on Students Social Activities at Elementary Level in Azad Kashmir Bagh
}

\author{
1 Dr Muhammad Mushtaq* ${ }^{2}$ Jabeen Syed $\quad 3$ Tehzib Mehreen
}

1. Assistant Professor, Department of Education, Women University of Azad Jammu \& Kashmir, Pakistan

2. M. Phil Scholar, Department of Education, Women University of Azad Jammu \& Kashmir, Pakistan

3. Lecturer, Department of Education, Women University of Azad Jammu \& Kashmir, Pakistan

\begin{tabular}{|c|c|}
\hline PAPER INFO & ABSTRACT \\
\hline $\begin{array}{l}\text { Received: } \\
\text { June } 07,2021 \\
\text { Accepted: } \\
\text { August } 10,2021 \\
\text { Online: } \\
\text { August } 17,2021\end{array}$ & $\begin{array}{l}\text { The study was designed to investigate the impact of home } \\
\text { assignment on student social and academic activities. The data was } \\
\text { collected to get information from } 300 \text { girls and boys elementary } \\
\text { students of public sector schools in district Bagh Azad Jammu and } \\
\text { Kashmir. The questionnaire was developed to get the information } \\
\text { about the impact of home assignment on student's social activities. }\end{array}$ \\
\hline $\begin{array}{l}\text { ds: Code } \\
\text { Activities, } \\
\text { ry Level } \\
\text { ignments, } \\
\text { Social }\end{array}$ & $\begin{array}{l}\text { The data was analyzed through SPSS } 23^{\text {rd }} \text { version and chi square test } \\
\text { was used. It was found that home assignments improved many } \\
\text { habits of the students like their learning, hand writing, study habits } \\
\text { and made the students responsible and punctual. Students after the }\end{array}$ \\
\hline $\begin{array}{l}\text { dr,muhammad.m } \\
\text { ushtaq@wuajk.e } \\
\text { du.pk }\end{array}$ & $\begin{array}{l}\text { completion of home assignments had enough time to participate in } \\
\text { different functions, time spent with their parents and friends. They } \\
\text { also took part in many indoor and outdoor extracurricular activities. } \\
\text { It is recommended that home assignments need to be planned } \\
\text { clearly and accurately that can be more beneficial for students. } \\
\text { Home assignments need to be arranged in the ways that they do not } \\
\text { look like a punishment for the learners; they could take part in other } \\
\text { additional activities. After the completion of home assignment the } \\
\text { teachers should provide their comments and feedback to the } \\
\text { learners. }\end{array}$ \\
\hline
\end{tabular}

\section{Introduction}

Home assignment is an important component of student's life. It is commonly observed that all students complete their home assignment from the early classes until graduation. There are two basic and common purposes of home assignments, first, the students learn useful and meaningful information from home assignments, second, home assignments create superior habits of learning and practices among students. Home assignments provide the students reinforcement, chances to make practices, application of the information, and transference reading, writing and thinking skills, following the directions, organizing materials, working independently and improvement of what is taught in school and wants students to integrate skills that included in curricula. This home work sometime forces parents who are unable to teach or give time to their 
children in tuition centers. Yadhav (2020) considered that the home assignments are a connection among institutions as well as homes for awareness to move back and forth, further adding that the time, learners use outside the school hours, is given the tricks to perform, emphasize and apply latest acquired skilled \& information and to discover basic skills of independent learning.

Olson (2018) raised the question whether the home work doer get higher grades and concluded that usually it happens but not necessarily this could be the only factor. Home assignments writing, are every child's nightmare. After a long tiring day at school, children have a lot of stress about school works, tests and general home assignments. Home assignment writing is what consumes a child's day after school along with the extracurricular activities. With the passage of time increasing competition and knowledge, home assignment is getting more demanding and complicated. Sometime even the parents are unable to help their children with writing home assignment solving a small math problem, reading the science subject and also in the submission of some assignment. At elementary level, learners having too many home assignments also create constant worry for both learners and parents, disturbance in their families, and not time to spend outside, playing games; meet their friends resting and extra activities. Home assignments and students extracurricular activities are strongly associated to each other. There are certain subjects that create more anxiety then the others.

Widjajanti, Listyani, \& Retnowati, (2020) recommended mathematics teachers to minimize home tasks because they create anxiety among students while they are anxious they could not be able to pay attentions to other subjects. Most of the activities apart from school are not being included in student's regular curricula and usually are to be held by the institutions and society. These activities consist of group sports, practical activities, arts performing, participationin schools other festivities. These activities promote the educational success on learners and many affirmative impacts on student's living skills and abilities.

Some other factors that play role in academic achievement while extracurricular and social activities offer chance for teacher and all learners to build associations and enhance their knowledge outside the school walls. Extracurricular activities improved academic performance, provide societal opportunities, enhance life skills, leadership, public speaking abilities. Sahito at el (2017) concluded that most of the tuition going students were highly motivated for future endeavors because they know the value of money, energy , attention and hard work which resulted in positive impact of tuition on their academic performance. Syeda, (2015) stated that most of the students join tuition centres for getting maximum benefit in realisation of their dreams by getting good grades and marks as school may not get enough time to complete all the task so tuition centre play this part. Mujahid \& Noman (2015) believed that teacher involvement is very low in proportionately so the contents and balance in curriculum development do not meet the standard and quality.

\section{Forms of Homework}

The homework assignments can be classified as written home assignments and oral learning assignments and these are awarded by schools teachers and tutors. Home assignment assigned to the children to be prepared outside the classroom is known as 
written homework. Home assignment gives opportunity to the students to discover and revise the material if they are puzzled by the topic in the classroom so they can seek assistance and give the child an alternative to learn at intervals.Chih-Hao, (2019) stated that the time spent by students for self study had significant positive effect on their learning while tutoring had also positive effect on their achievement. Oral homework is the process of expression, information and thoughts by words of mouth. Oral fluency or oral communication is very important for child. It develops the major skills of speaking. The home work builds the students conversation and speaking skills also. At elementary level oral work increases the confidence level. Private tutoring is becoming more and more popular in all countries that hardly surprises as it has many positive effects in improving student's academic grades, however also their understanding of broad area of subjects. They teach different subjects in tuition such as English, Math, Science, History, Computer etc.

\section{Nature of Homework}

There are many types of homework practices, creation, preparation, practice and homework meant to increase learning and help all the students' master specific skills and abilities. In practice homework students apply new knowledge, reinforcement of recently acquired and received skills for example memorization of mathematical table, practicing spelling words, essay writing and story writing.

This can help learners integrated multiple concepts, promote and encourage the maturity of intellectual judgment and talent to resolve the problems for example science project, experiment and poster competition.

Preparation homework introduces the material that is presented in future lesson. In preparation type students are assigned to read a chapter from their course book, then students are asked to observe and read it carefully and document something independently outside from the school environment after then their observation will be used as the basic for the next lesson.

The anxiety of school is pounding down on several students. A number of hours of school moreover with home assignments can be a lot for any one. The time spentin classroom and the time spent in school work may go ahead to student's sense of overwhelmed and unmotivated. Students are not capable to fulfill further requirements like bodily and communally energetic because they spent their extra time on home assignment. Because of the additional activities and societal time students get an opportunity to energize their mind and body but those learners who have huge amount of home assignment were unable to have enough time to provide company with their family members and companion, so they may feel themselves lonely and hopeless.

\section{Education as a Process}

Education prepares and trains the child for mature life in which he will be able to take and fulfill his responsibility of adult and coming real life. It is training for a living a life here and hereafter. A previous Sanskrit quotation saying: "Education guides to deliverance - deliverance as of unawareness that covers the brain; deliverance from false 
notion which blind the image of exactness. According to Umoh (2006), education helps all the individuals to develop physically, mentally, spiritually and also emotionally by providing appropriate environment, teaching him latest knowledge, attitudes and skills that facilitate him to be valuable to himself and his society. The real aspiration of education is to develop in the body and soul all the attractiveness and all perfection of which they are capable of. Education is the name of training for completeness of life' and propose the character of men and women for solving the conflict of coming life according to their desires. Hussian (2016) identified that failing in grades is directly result of less focus on home work so a policy is required to restrict teachers for making reasonable amount of homework daily weekly and monthly . The basic aim and intention of education is developing of physical, intellectual, emotional and ethical amalgamation of the individual into a complete man and it is also an extensive description of education.

\section{Child Personality Development}

Personality developments can be explained as the development of organized sample of behaviors and attitudes that makes anyone distinguishing and making him different from others. The combination of thoughts and feelings of someone is known as personality. Temperament, environment and character are the main components of child's personality. Temperament is the first component of personality, this is a set of heritably determined persona and characteristics. The next element of personality is environment and performs a central responsibility in the growth of child's personality. The development of human beings personality the most effected by environment and temperament equally. Character is the third factor of personality. This is the set of emotions, intellectual and behavioral pattern that happen from the practice. The meaning of personality development in a child can be described as, identifying the potential abilities, confidence, dispositions and, awareness of self, development of talent, acceptance the responsibilities for him and others, societal abilities, improving the mental and physical fitness.

\section{Students Social Activities}

The planned and unplanned outdoor activities out of the classroom are known as social or extracurricular activities. These activities will provide the essential skills with encouragement of a strong lifestyle. . Harrison\& Narayan (2003) said that taking part in extracurricular activities provides lot of advantages for students as these structured activities authorize students to construct strong relationships with adults and attain affirmative role models. According to Fredricks (2006), extracurricular activities contribution can be associated to positive academic ending, as well as improved grades, assessment scores, more school commitment and develop educational aspiration.

\section{Homework Policy}

The valuable homework policies are supported by all families and teachers. When refining the home assignment practices never abandon the both groups (students and parents) it is said by all researchers, organization and administrators of schools. They emphasis explicitly on these aspects and purposed that quality and nature of homework, feedback, support, teacher collaboration need to be coherent and cohesive. Marzano \& Pickering (2007). A well and good homework policy consist many things such as. 
1. Relax time (chill out /rest time).

2. After school play

3. Recreational reading (leisure time)

4. Sport (games and activities)

5. Socializing with friends and family

Learner's physical and intellectual health may equally influence because of home assignments. Over home assignment may effect in short of asleep, headache, tiredness also losing of weight. . Student who makes efforts with home assignment each night can be depressing effect on their family and social relationship.

\section{Material and Methods}

The study was based on population, sample, research instruments, data collection and procedure used for the analysis of the data.

\section{Population}

In first phase 73 public schools were population of the study while target/research Populations was determined as 30 public schools and students enrolled there were 4500 .

\section{Sample} out of it.

The researcher used convenient sampling techniques and selected 300 students

\section{Research Tool}

Questionnaire about the home assignment effect on student's social activities was used in this study.

\section{Data Analysis}

The questionnaire were distributed and collected back, data was coded and put into SPSS. The data was analyzed by using different statistical techniques. The following tables were drawn to determined finding and recommendations.

Table 1

Positive Effect of Homework on Child

\begin{tabular}{lccc}
\hline Statement & $\mathbf{X}^{\mathbf{2}}$ & df & Asymp sig \\
\hline Home work is useful for us. & 531.767 & 4 & .000 \\
\hline Homework improve the child learning. & 426.333 & 4 & .000 \\
\hline Homework improve child hand writing. & 369.567 & 4 & .000 \\
\hline Homework improve my study habits. & 291.900 & 4 & .000 \\
\hline Homework makes me responsible and punctual. & 311.05 & 4 & .000 \\
\hline
\end{tabular}


Table 1 item no 1 indicated that home work is useful for the respondents as $\mathrm{X}^{2}$ value is 531.767 at df 4 and significant level .00 , item no 2 indicated that Home work improves child learning as $\mathrm{X}^{2}$ value is 426.333 at $\mathrm{df} 4$ and significant level is .000 , item no 3 indicates that homework improves the child handwriting as $\mathrm{X}^{2} 369.567 \mathrm{df} 4$ and significant level is .000 , itme no 4 explains that homework improves study habits of the students as the value $\mathrm{X}^{2} \mathrm{df} 4$ and significant level .00, item no 5 displays that homework make students responsible and punctual in learning activities as indicated in $\mathrm{X}^{2}$ value $\mathrm{df} 4$ and significant level .000 .

Table 2

Negative Effect of Homework on Child

\begin{tabular}{lcccc}
\hline \multicolumn{1}{c}{ Statement } & $\mathbf{X}^{2}$ & df & Asymp sig. \\
\hline Homework causes stress for me & 140.100 & 4 & .000 \\
\hline $\begin{array}{l}\text { Time for other activities is short due to } \\
\text { homework. }\end{array}$ & 78.767 & 4 & .000 \\
\hline I always need help in completing homework & 103.733 & 4 & .000 \\
\hline $\begin{array}{l}\text { Participation in sports \& games is difficult when I } \\
\text { get homework }\end{array}$ & 88.967 & 4 & .000 \\
\hline \begin{tabular}{l} 
I am tired while doing my homework \\
\hline
\end{tabular} & 113.100 & 4 & .000 \\
\hline
\end{tabular}

The table 2 show negative effect of the home work as homework cause stress for students, they do not spare time for other activities, they always need help in complete their homework, homework proved difficult for them, no time for exercises, no participation in sports and games and students feel tired while they are doing their homework.

Table 3

Effect of homework on Indoor activities

\begin{tabular}{lccc}
\hline Statement & $\mathbf{X}^{\mathbf{2}}$ & df & Asymp.sig \\
\hline I play games in computer & 214.000 & 4 & .000 \\
\hline I listen music in free time & 199.967 & 4 & .000 \\
\hline I watch television & 318.533 & 4 & .000 \\
\hline I regularly watch cartoon on T.V & 152.167 & 4 & .000 \\
\hline
\end{tabular}

Table no 4 shows respondents take part in many indoor activities. they are play games in computer, listen music in free time, watch TV and cartoon.

Table 4

Outdoor activities

\begin{tabular}{lccc}
\hline Statement & $\mathrm{X}^{2}$ & $\mathrm{df}$ & Asymp. sig \\
\hline I read newspaper and stories book & 279.833 & 4 & .000 \\
\hline I do gardening in free time & 70.400 & 4 & .000 \\
\hline I have time to enjoy dance \& join club & 238.700 & 4 & .000 \\
\hline I visit library daily & 77.233 & 4 & .000 \\
\hline
\end{tabular}

This table indicates that respondents not like to read newspaper and stories book. They do not like to gardening in free time but they have enough time to enjoy dance and join club and visit library daily. 


\section{Discussion}

The present study explored the effect of home assignments on student's social and academic activities. For this purpose data was collected from middle schools students. Home assignments are useful for the students but it has many positive and negative effect as home assignments improve the students learning, made the students more responsible and punctual, connection among the students, teachers and parents, a big source of improvement in the students hand writing but as well it has many negative effect such as causes stress in students, they feel tired, not time to spend with their families and unable to take part in many other extracurricular activities. This studies shows that the positive effects are more than the negative effects and it is imperative to improve learner's skills so home assignment does not hinder improvement in the various skills but enhanced these skills and most of time they perform other activities after they had done their home assignments.

Burnett (2007) concluded there is prosperity of facts to maintain the argument that there are many valuable outcomes on learning performance and attainment in the contribution of supplementary activities and further area of psychological functioning additionally. The study stated that $48.3 \%$ student take part in institutional supporter actions and $21.7 \%$ students participate in outside activities. This indicates a significant relation between extracurricular activities and home assignments, whereas this study shows the strong and positive relation between the extracurricular activities and homework. Students have time for other indoor and outdoor activities.

Vatterott (2009) concluded after surveying numerous students that home environments for studying is poor. To complete their home assignment their parents cannot facilitate them. This means student always need help in completing their home assignments. There are 19\% students that agree from this statement, $42 \%$ disagree and $30 \%$ disagree. Whereas the present study showed a positive effect of home assignments that student need no help for the completion of their assignments

There is no doubt that home assignments or home work given by schools is always useful and productive as the research study shows and similar studies were already conducted in different areas of the world and they proved it as Deswal and Rani \&Alwhat(2014) and Yale (2019) where they all focus on parental role in assistance of completing home assignments. It is the parents role their motivation and encouragement by them that play significant role in academic performance of the child. Rose and Barrow (2006), Mayer (2010) believed that the parents financial strength and richness has positive role on their academic performance as they spend more on education, their interaction with better placed people and the care they get from family and peers but I think is too biased opinion because certainly there are children whose parent were not rich but they have achieved highest level of success .Younas\& Noor (2020) concluded that educational activities and family expectation are mostly interconnected with other factors like socio economic status, as it creates different learning environment for the children so it could be deducted that resources play some role but not all the role and the organism itself has dynamics which play important role. Sund\&Gericke (2020), Fadda, Afzal and Haberman (2020) pointed out that teachers role is very significant in terms of assigning home assignments their nature and the energy they required to achieve it. So 
careful planning of home assignments could definitely bring a very good results in terms of academic and social performance.

\section{Conclusion}

The procedure of home assignments involves three main imperative characters learners, guardians and instructors. All of these characters play very significant role in the completion of home assignments and child other activities. The findings of data analysis showed that there are many beneficial aspect of home assignment as these assignments make students responsible, punctual, improve the students hand writing, and develop the learning habits. There are some negative effects of home assignment as: students feel stress due to assignments; they do not participate in indoor and outdoor activities they need help in completion of home assignment

\section{Recommendation}

Home work should be planned clearly and accurately so that it could be used for reader benefit of the students. Home assignments are likely to create connection between students, teachers and parents. Teachers may hold on PTM on monthly basis and aware the parents to students progress in class.

a) Teacher may give home assignments on daily basis because home work proved useful for students and increases their learning. Teacher should plan such home assignments that never prove punishment and burden for student. Students may be given enough time of relaxation that they could enjoy other extracurricular activities.

b) Teachers should suggest home assignments that could be completed easily as too much home assignments increase stress in students.

c) Teacher should help the child by giving quality home assignment as extra home assignments make the child feelings of boring and tired and always need help for completion their home assignment.

d) Teacher may give appropriate and time consuming home assignments because too much home assignment creates a sense of tired in students they have no time for other activities

e) Teacher may arrange the home assignments clear fully, clarify it, and make assignment easy for students. After completion of assignment by student teachers should give their feedback and comments

f. Teachers may give the time to the students that they can take part in other extracurricular activities.

g. Teacher may give home assignments that increase the various developmental students' skills.

h. Teacher should over burden students with home assignments but keep it flexible and give the time to their peer relation in school and in family circle. 


\section{References}

Barnett, L.( 2007). Winners and losers: The effect of being allowed or denied entry into competitive extracurricular activities. Journals of Leisure Research, $39(2), 316-244$.

Chih-Hao, C. (2019). Effects of private tutoring on English performance: Evidence from senior high students in Taiwan. International Journal of Educational Development, 68, 80-87.

Cordova, C., Pagtulon-an, E. A., \& Tan, D. A. (2019). NO ASSIGNMENT POLICY: A BOON OR A BANE? International Journal of English and Education, 8(1), 144-160.

Davidovitch, N., \&Yavich, R. (2017). Views of Students, Parents, and Teachers on Homework in Elementary School. International Education Studies, 10(10), 90-108.

Deswal, Y. S., Rani, R., \&Ahlawat, S. (2014). Impact of home environment on academic achievementof adolescent students in relation to their locality and type of school. Bharatiyam International Journal of Education and Research, 3(3), 42-49.

Widjajanti, D. B., Listyani, E., \&Retnowati, E. (2020, July). The profile of student mathanxiety. In Journal of Physics: Conference Series (Vol. 1581, No. 1, p. 012059). IOP Publishing.

Fadda ,H., Afzaal ,M. ,Haberman, P. (2020). Dynamic Assessment in Education: A CaseStudy of Chinese-Speaking EFL Classroom. Universal Journal of Educational Research, 8(12),6967 - 6977. DOI: 10.13189/ujer.2020.081264.

Fredricks, J. A. (2006). Is extracurricular participation associated with beneficial outcomes? Concurrent and longitudinal relations, Developmental psychology, 42(4), 698

Harrison, P. A. \& Narayan, G. (2003). Difference in behavior, psychological factors \& environmental factors associated with participation in school sports and other activities in adolescence. Journals of school health 73(3), 113-120.

Huisman, C. (2016). Perceptions of the Effects of Homework on Student Achievement at ASuburban Middle School: A Program Evaluation. National Louis University.

Marzano, R. J. \& Pickering, D, J. (2007). The case for and against homework. Educational leadership, 64(6), 74-79.

Mayer, S. E. (2010). Revisiting an old question: How much does parental income affect child outcomes. Focus, 27(2), 21-26.

Mujahid, N., \& Noman, M. (2015). Infrastructure availability in the public sector schools: A Case study of Sindh Province. Journal of Education and Practice, 6(4), 60-68. 
Olson, K. A. (2018). Do Upper Elementary Students Have Higher Grades When They Complete Their Homework? Master theses and Capstone Projects Northwestern College - Orange City

Ormord, J. E. (2003). Educational psychology: Developing learners. (Rev/expanded Upper Saddle River, NJ: Merrill/Prentice Hall.

Rouse, C. E., \& Barrow, L. (2006). US Elementary and secondary schools: equalizing opportunity orreplicating the status quo? The future of children, 16(2):99-123

Sahito, Z., Khawaja, M., Siddiqui, A., Shaheen, A., \& Saeed, H. (2017). Role of Tuition Centers in the Performance and Achievement of Students: A Case of Hyderabad District, Sindh, Pakistan. Journal of education and training studies, 5, 90-102.

Sund, P., \&Gericke, N. (2020). Teaching contributions from secondary school subject areas toeducation for sustainable development-a comparative study of science, social science and languageteachers. Environmental Education Research, 26(6), 772-794.

Syeda, T. J. (2015). Perceptions of private college teachers of Karachi about the curriculum prescribed by Sindh Bureauof Curriculum (BOC). ActaDidacticaNapocensia, 8(4), 1324.

Umoh, G. (2006). Path to quantitative education: A standard book for students, teachers and educational administrators. UyoInehaVentrus and publishers.

Vatterott, C. (2009). Rethinking Homework. Best practices that support Diverse, Association for Supervision and Curriculum Development 1703 N. Beauregard St. Alexandria

Need. Cooper, H. (2010, December 12). Homework Diminishing Returns. The New York Time

Wakefield, J. F. (1996). Educational Psychology: Learning to be a problem solver. Houghton Mifflin.

Wolfe, P. (2001). Brain matter. Translating research into classroom practice. Alexandria, VA: Association for Supervision and curriculum development.

Yadhav, B. K. (2020). Student's Attitude Towards Homework (Doctoral Dissertation). Tribhuvan University Kirtipur, Kathmandu Nepal

Yale, A. T. (2019). The personal tutor-student relationship: student expectations and experiences of personal tutoring in higher education. Journal of Further and Higher Education, 43(4), 533-544.

Yavich, R., \&Davidovitch, N. (2020). Homework: At Home or At School?--Attitudes of Teachers, Parents and the General Public: A Case Study. International Education Studies, 13(6), 170-179. 
Younas, M., \& Noor, U. (2020). Teaching for Excellence and Equity: Analyzing Teacher Characteristics, Behaviors, and Student Outcomes with TIMSS. Journal of International Students, 10(4), 1114-1116. 